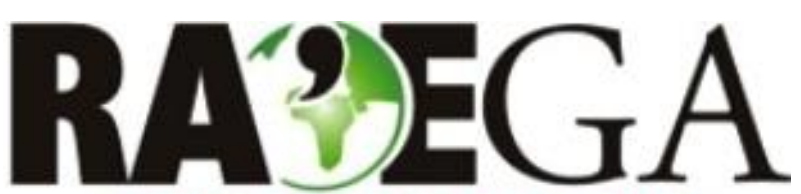

O ESPAÇO GEOGRÁFICO EM ANÁLISE

\title{
EXPANSÃO URBANA E IMPACTOS AMBIENTAIS NA ZONA COSTEIRA NORTE DO MUNICÍPIO DE SÃO LUÍS (MA)
}

URBAN EXPANSION AND ENVIRONMENTAL IMPACTS ON COAST NORTH OF SÃO LUÍS (MA)

\author{
Janilci Serra Silva ${ }^{1}$, Marcelino Silva Farias Filho ${ }^{2}$
}

\section{RESUMO}

Em razão da supervalorização da Zona Costeira, observa-se que esses espaços têm sido cenários de intensos processos de alteração do uso e ocupação do solo e isto tem criado um espaço cada vez mais antropizado. Esta é uma problemática observada em todo o espaço costeiro brasileiro e, nesta pesquisa, destacamos a Zona Costeira Norte de São Luís (MA). O principal objetivo deste estudo foi analisar as alterações do uso e ocupação do solo da Zona Costeira Norte de São Luís entre os anos de 1984 e 2010, utilizando dados multitemporais do sensor TMLandsat 5. Foram utilizadas duas imagens de satélite referentes aos dias 20/06/1984 e 04/02/2010. A classificação foi realizada em ambiente SIG (Sistema de Informações Geográficas) e o software utilizado foi o Spring 5.2.7. Na classificação foram mapeadas quatro classes: (1) urbano, (2) vegetação, (3) solo exposto e (4) água. O resultado da classificação do uso e ocupação da Zona Costeira Norte de São Luís mostrou que, no ano de 1984, a área urbana ocupava um total de $29,27 \%$ da área analisada, e no ano de 2010 , passou a ocupar um total de 56,26\%, evidenciando, o intenso processo de alteração da paisagem natural.

Palavras-chave: Sensoriamento remoto, uso e ocupação, urbanização, área de preservação.

\section{ABSTRACT}

Due to the overvaluation of the Coastal Zone, it is observed that this local has been a scenario of intense alteration processes of the use and occupation of the soil and this has created an increasingly anthropized area. This is a problem observed throughout all the Brazilian coastal area and in this research we highlight the North Coastal Zone of São Luís (MA). The main objective of this study was to analyze changes in the use and occupation of the soil in the North Coast Zone of São Luís between the years of 1984 and 2010, using multi-temporal data from the TM/Landsat 5 sensor. Two satellite images were used, referring to the days of the 20th July 1984 and 4th February 2010. The classification was defined using a Geographic Information System (GIS) technology, and the Spring 5.2.7 software. Four classes were mapped in the classification: (1) urban (2) vegetation (3) exposed soil and (4) water. The result of the classification of the use and occupation of the North Coastal Zone of São Luís showed that, in the year of 1984, the urban area occupied a total of $29.27 \%$ of the analyzed area, and, in 2010, it occupied a total of $56.26 \%$, evidencing the intense alteration process of the natural landscape.

Key-words: Remote sensing, use and occupation, urbanization, preservation area.

Recebido em: 19/05/2017

Aceito em: 20/02/2019

\footnotetext{
${ }^{1}$ Universidade Estadual de Campinas, Campinas/SP, e-mail: janilciserra@hotmail.com

${ }^{2}$ Universidade Federal do Maranhão, São Luís/MA, e-mail: marcelino.farias@ufma.br
} 


\section{EXPANSÃO URBANA E IMPACTOS AMBIENTAIS NA ZONA COSTEIRA NORTE DO MUNICÍPIO DE SÃO LUÍS (MA)}

\section{INTRODUÇÃO}

A Zona Costeira é um espaço complexo que está em constante modificação, resultado da interação de processos naturais, relacionados com a escala temporal e sobre efeitos da ação antrópica. A Zona Costeira apresenta em sua configuração diversos ecossistemas que se alternam entre mangues, praias, campos de dunas, estuários, além de outros ambientes, por isso, se configura como um ambiente de significativa riqueza natural (DIAS e OLIVEIRA, 2013, p. 372).

De acordo com o IBGE (2011, p. 117), no Brasil, aproximadamente $26,58 \%$ da população vive em municípios da Zona Costeira. Parte dessa população está ocupada em atividades ligadas ao turismo, de forma direta ou indireta, e nos serviços que atendem à dinâmica econômica gerada por esses municípios e outros próximos.

Diversas pesquisas têm mostrado a influência que o homem exerce na alteração da paisagem natural da Zona Costeira, destacamos aqui os estudos de Kawakubo et al. (2003), Silva et al. (2008), Meireles (2008), Paula et al. (2013), Dias e Oliveira (2013), Lima e Amaral (2013) e Silva e Farias Filho (2015).

Ainda com relação ao processo de ocupação da zona costeira, Silva e Silva (2007, p. 28), constataram que "as praias têm sido um dos primeiros ambientes a sofrer diretamente os impactos da expansão das atividades econômicas ligadas ao turismo, recreação e lazer, e do consequente adensamento demográfico".

A percepção e o somatório de todas essas atividades relacionadas ao uso e ocupação não planejados da Zona Costeira têm gerado, portanto, diversos impactos ambientais. Desta maneira, salienta-se que essa discussão merece atenção especial, considerando a importância significativa da diversidade dos ecossistemas localizados no espaço geográfico brasileiro.

Um dos elementos que possibilitam o processo de planejamento e gestão integrada da Zona Costeira tem a ver com os planos e leis direcionados para as questões de proteção do ambiente natural e ordenamento territorial, cujo objetivo é essencialmente auxiliar o uso sustentável desse ambiente, integrando desenvolvimento socioeconômico, valorização e proteção ambiental e defesa costeira, de acordo com as condições próprias de cada lugar. Um exemplo disso é a Lei de Zoneamento, Parcelamento, Uso e Ocupação do Solo, Plano Diretor, Lei Orgânica Municipal e Projeto Orla.

Nesse contexto, cabe ressaltar a constante necessidade de implementação de estudos ambientais, capazes de integrar o planejamento e gestão racional do uso e ocupação do solo na Zona Costeira, porquanto se credita importante e necessária a existência de monitoramento constante desses espaços. Como forma de monitoramento destaca-se o uso das técnicas de sensoriamento remoto.

Os processos de monitoramento do uso e ocupação do solo, a partir de técnicas automáticas e interpretações visuais de produtos de Sensoriamento Remoto vêm sendo utilizados de forma eficiente e têm subsidiado o processo de gestão das cidades. Nesse contexto, destaca-se o uso das imagens de satélite, que além de apresentar um excelente resultado no processo de monitoramento das cidades, traz a vantagem de ser uma ferramenta de baixo custo.

Diante de tais considerações, a pesquisa que ora se apresenta tem como área de estudo a Zona Costeira do município de São Luís (MA). A Zona Costeira Norte de São Luís segue o mesmo padrão observado nas demais áreas do litoral brasileiro, considerando que se caracteriza por intensos processos de uso e ocupação ocorridos, na maioria das vezes, sem levar atentar-se para a necessidade de conservação das características naturais desses espaços.

Ainda sobre essa área, em meados das décadas de 1970, o acesso para a costa da cidade de São Luís foi sendo facilitado, em razão da construção de algumas pontes, como a ponte José Sarney e a Ponte Bandeira Tribuzi. 


\section{EXPANSÃO URBANA E IMPACTOS AMBIENTAIS NA ZONA COSTEIRA NORTE DO MUNICÍPIO DE SÃO LUÍS (MA)}

Desta forma, o processo de ocupação da Zona Costeira foi intensificando.

A Zona Costeira da região Norte de São Luís, além de comportar percentual populacional bastante significativo, o que demanda diferentes necessidades e interesses, contém também potencialidades econômicas e naturais que devem ser exploradas em conformidade com os instrumentos de gestão territorial. Sendo assim, a justificativa para o desenvolvimento deste estudo partiu da necessidade de compreender as alterações que ocorreram na paisagem natural da Zona Costeira Norte de São Luís e, assim, subsidiar futuros projetos de gestão territorial do uso e ocupação desse espaço.

Sob a égide desse propósito, o objetivo desta pesquisa foi analisar as alterações do uso e ocupação do solo da Zona Costeira Norte de São Luís, entre os anos de 1984 e 2010, utilizando dados multitemporais do sensor TMLandsat 5 , além de analisar os instrumentos de gestão territorial (lei de Zoneamento, Parcelamento, Uso e Ocupação do Solo, Plano
Diretor e a Lei Orgânica Municipal) que são aplicados ao planejamento do uso e ocupação da área de estudo.

\section{LOCALIZAÇÃO E CARACTERIZAÇÃO DA ÁREA DE ESTUDO}

A área de estudo analisada nesta pesquisa é a Zona Costeira Norte do município de São Luís - MA que está localizada entre as coordenadas $2^{\circ} 30.308^{\prime} \mathrm{S}$ e $44^{\circ} 9.108^{\prime} \mathrm{O}$; $2^{\circ} 27.786^{\prime}$ e $44^{\circ} 10.920^{\prime} O$, abrangendo os bairros de Ponta d'Areia, Ponta do Farol, São Marcos, Calhau e Olho d'Água (Figura 1).

O município de São Luís, localiza-se na Ilha do Maranhão e faz parte da microrregião da Aglomeração Urbana de São Luís, está inserido na Mesorregião Norte Maranhense. $\mathrm{Na}$ ilha do Maranhão localizam-se quatro municípios: São Luís, São José de Ribamar, Paço do Lumiar e Raposa e juntos com outros municípios formam a Região Metropolitana da Grande São Luís.

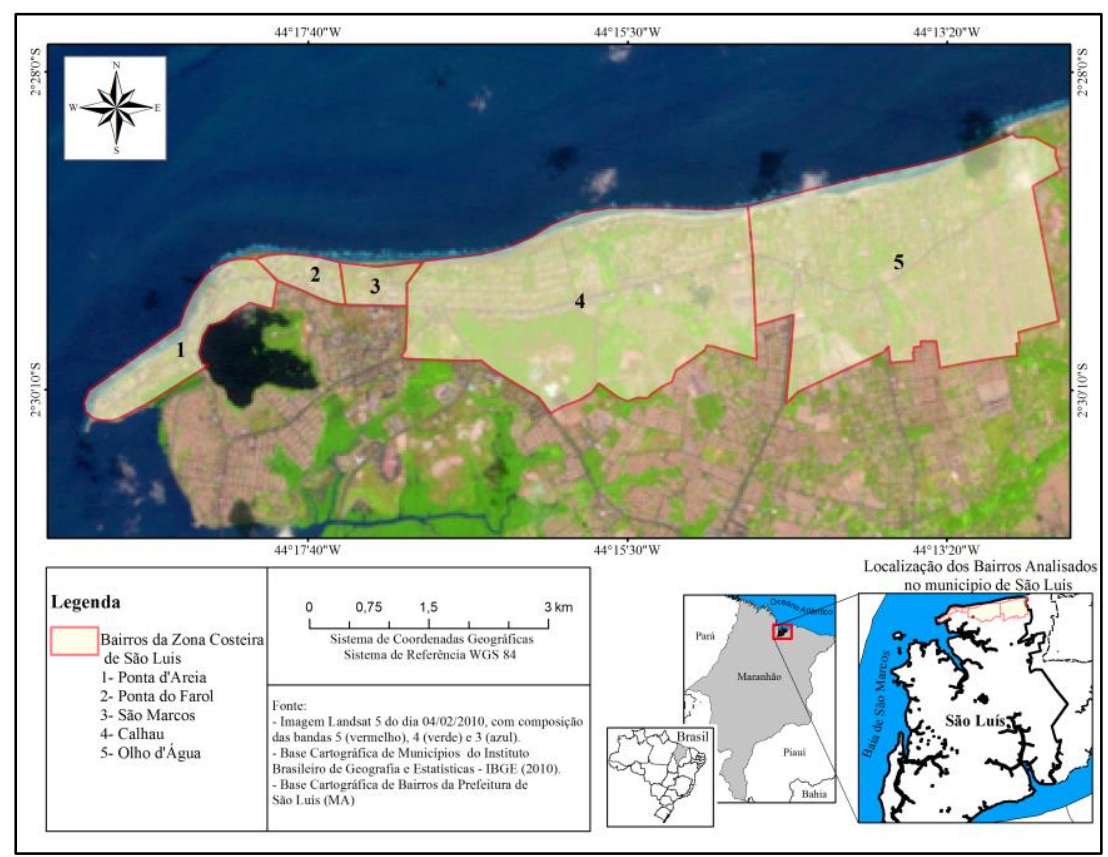

Figura 1 - Localização da área de estudo - Bairros da Zona Costeira Norte de São Luís (MA). Fonte: Organizado pelos autores (2016).

A cidade de São Luís, capital do Maranhão, formou-se na península que avança sobre o estuário dos rios Anil e Bacanga, estando a uma altitude média de $24 \mathrm{~m}$. Limita- 


\section{EXPANSÃO URBANA E IMPACTOS AMBIENTAIS NA ZONA COSTEIRA NORTE DO MUNICÍPIO DE SÃO LUÍS (MA)}

se com o Oceano Atlântico, ao Norte; com o Estreito dos Mosquitos, ao Sul; com a Baía de São Marcos, a Oeste.

Salienta-se , na área de abrangência da Zona Costeira de São Luís, existem outros espaços que também apresentam problemáticas ambientais, no entanto, o recorte da área que foi estudada nesta pesquisa ocorreu devido ser neste local onde a expansão urbana tem acontecido de forma mais acelerada em função da supervalorização desse espaço e da especulação imobiliária.

\section{1. $O$ crescimento urbano de São Luís (MA)}

De acordo com Marques (2006, p.63), o processo de ocupação de São Luís (MA) teve início no período Colonial e Imperial. A urbanização, por sua vez, teve início a partir da ocupação do bairro Praia Grande, localizado na confluência dos rios Bacanga e Anil. Desde então, a cidade foi se expandido para outros espaços e essa expansão foi desencadeada sobremaneira em decorrência da criação de um parque fabril têxtil no fim do século XIX.

No período compreendido entre as décadas de 1970 e 1980, São Luís experimentou um rápido crescimento da população. Sobre esse fato, Diniz (2007, p. 172) esclarece que, entre as décadas mencionadas, o intenso adensamento populacional ocorreu em razão da criação de algumas indústrias que funcionaram como um atrativo econômico, e contribuíram para a expansão demográfica que a cidade possui nos dias atuais. $O$ autor explicita:

\begin{abstract}
As décadas de 70 e 80 foram marcadas a nível econômico basicamente pela instalação de grandes capitais industriais [...]. Todos esses eventos proporcionaram à cidade várias mudanças, sendo uma delas o aumento do contingente populacional, que no período de 70/80 praticamente duplicou. Em virtude desse crescimento, a cidade apresentou problemas de ordem sócio-econômica bastante visíveis. O crescimento populacional desordenado trouxe problemas de habitação, saúde, segurança e favoreceu o surgimento de ocupações irregulares, palafitas e favelas, problemas esses que têm evoluído consideravelmente, à medida que a urbanização cresce.
\end{abstract}

A figura 2, apresenta os dados de crescimento demográfico de São Luís, no período de 1970 a 2010. De acordo com a análise da Figura 2, observa-se que o crescimento da população do espaço urbano de São Luís tem sido cada vez mais intensificado, uma característica que segue o padrão nacional de reorganização do espaço urbano das cidades. Essa intensificação se dá, entre outras razões, pela emigração ocorrida no campo a partir do processo de êxodo rural, que alavancou o crescimento populacional na zona urbana das cidades, inclusive São Luís.

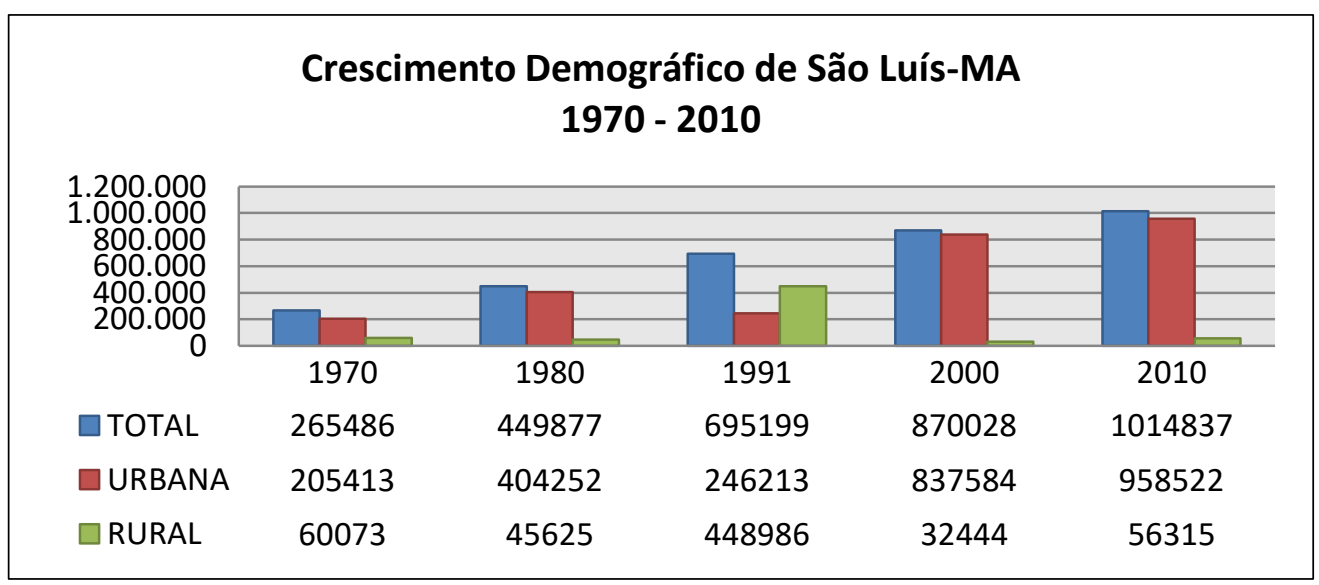

Figura 2 - Crescimento demográfico de São Luís - MA, no período de 1970-2010. Fonte: Censo demográfico IBGE 1970- 2010. Adaptado pelos autores. 


\section{EXPANSÃO URBANA E IMPACTOS AMBIENTAIS NA ZONA COSTEIRA NORTE DO MUNICÍPIO DE SÃO LUÍS (MA)}

Em consonância aos dados referentes ao ano de 1991, em que alguns indicadores do IBGE foram espacializados de forma errada, nota-se que a zona rural apresenta um índice demográfico acima do quantitativo que de fato existia. Segundo Diniz (2007, p. 171) "tal fato deve-se, quando do recenseamento, alguns locais da cidade de São Luís, a exemplo do Anil, foram considerados como zona rural, muito embora se tratasse de população eminentemente urbana".

A rápida expansão demográfica do município de São Luís - MA, associada à demanda crescente pelo uso do solo para assentamento humano e implantação de outras edificações (indústrias, equipamentos urbanos entre outros), caracterizou a mudança da paisagem natural, transformando-a em uma paisagem cada vez mais artificial. De acordo com Santos (1997, p. 64), "a paisagem artificial é a paisagem transformada pelo homem, enquanto grosseiramente podemos dizer que a paisagem natural é aquela ainda não mudada pelo esforço humano".

Esse processo de ocupação do espaço urbano, quando não ocorre de forma planejada, pode desencadear uma série de conflitos em diversas escalas e seguimentos (sociais, econômicos e ambientais). A exemplo, apresenta-se o caso da ocupação da Zona Costeira do município de São Luís - MA, que tem sido cada vez mais utilizada de maneira inapropriada, descumprindo as normas de uso e ocupação estabelecidas nos instrumentos de gestão urbana.

\section{MATERIAIS E MÉTODOS}

Esta pesquisa foi desenvolvida com base na interpretação de produtos de sensoriamento remoto, trabalhos de campo e consulta ao referencial teórico sobre a temática abordada. As etapas do estudo serão mais bem detalhadas a seguir.

A primeira etapa consistiu na revisão do referencial teórico sobre os temas: impactos ambientais na Zona Costeira, leis e diretrizes de gestão do uso da terra, gestão urbana, uso e ocupação do solo da Zona Costeira de São Luís MA. Foram analisadas leis como o Estatuto da Cidade, do Plano Diretor de São Luís, do Plano Nacional de Gerenciamento Costeiro, da Lei Orgânica e a da Lei de Zoneamento, Parcelamento Uso e Ocupação do Solo Urbano de São Luís.

A segunda etapa consistiu da análise das formas de uso e ocupação do solo por meio da classificação de imagens de satélite Landsat 5 , sensor TM, cuja resolução espacial é de 30 metros, da órbita 220 e ponto 62, disponibilizadas pelo United States Geological Survey (USGS). Foram analisadas duas imagens, nas seguintes datas: 20 de julho de 1984 e 04 fevereiros de 2010. O Sistema de Informação Geográfica (SIG) utilizado para o préprocessamento e processamento das imagens, foi o spring 5.2.7, disponibilizado gratuitamente pelo INPE (Instituto Nacional de Pesquisas Espaciais, Brasil).

A etapa do pré-processamento incluiu o georreferenciamento das imagens de satélite. Para fazer o georreferenciamento, foram coletados pontos de controle durante a atividade de campo. $\mathrm{Na}$ atividade de campo foram coletados 10 pontos de controle, utilizando-se, para isso, o GPS-45 Garmin. Vale ressaltar que, durante a etapa do trabalho de campo, foi identificada também a localização dos principais impactos ambientais da Zona Costeira Norte de São Luís ocasião em que foi feito registro fotográfico

Para o processamento da imagem, foi realizada a classificação do uso e ocupação do solo (bairros da Zona Costeira de São Luís MA). Em seguida, foram elaborados os gráficos com a quantificação da área ocupada por classe. $\mathrm{Na}$ classificação, foi utilizado o classificador MAXVER, considerando o limiar de aceitação de $100 \%$. Em função do objetivo geral deste estudo, optou-se pela elaboração de uma legenda simplificada, com apenas quatro classes. Foram identificadas as seguintes classes: urbano, vegetação, solo exposto e água. Após o mapeamento das classes, foi realizada a edição matricial (pós-classificação), 


\section{EXPANSÃO URBANA E IMPACTOS AMBIENTAIS NA ZONA COSTEIRA NORTE DO MUNICÍPIO DE SÃO LUÍS (MA)}

para corrigir alguns erros de classificação. Tais erros podem ter ocorrido devido à similaridade de respostas espectrais entre os diferentes alvos.

Após a classificação digital das imagens, foi feita a validação das amostras das classes mapeadas. Essa etapa teve como objetivo avaliar a acurácia da exatidão da classificação.

Para a elaboração dos gráficos e cálculos da taxa de variação de cada classe mapeada, foi utilizada a planilha eletrônica Excel do pacote Office 2010.

\section{ANÁLISE DOS RESULTADOS}

\subsection{Classificação do uso e ocupação da terra} na Zona Costeira de São Luís

Da classificação multitemporal das imagens de satélite, resultou o mapeamento de
4 classes: urbano, vegetação, solo exposto e água. A Figura 2 mostra a espacialização das classes de uso e ocupação da terra na Zona Costeira Norte de São Luís para o ano de 1984, enquanto a Figura 3 apresenta o resultado da classificação para o ano de 2010. Nota-se que a classe de vegetação ocupava maior área no ano de 1984, e no ano de 2010 houve significativa redução desta classe. Percebe-se ainda que, na comparação entre a classificação de 1984 e 2010, a área pertencente à classe urbana teve elevado crescimento, evidenciando a expansão da área urbanizada na Zona Costeira Norte de São Luís. No que se refere à classe de solo exposto, é possível observar que o ano de 2010 houve maior representação desta classe, se comparado ao ano de 1984.

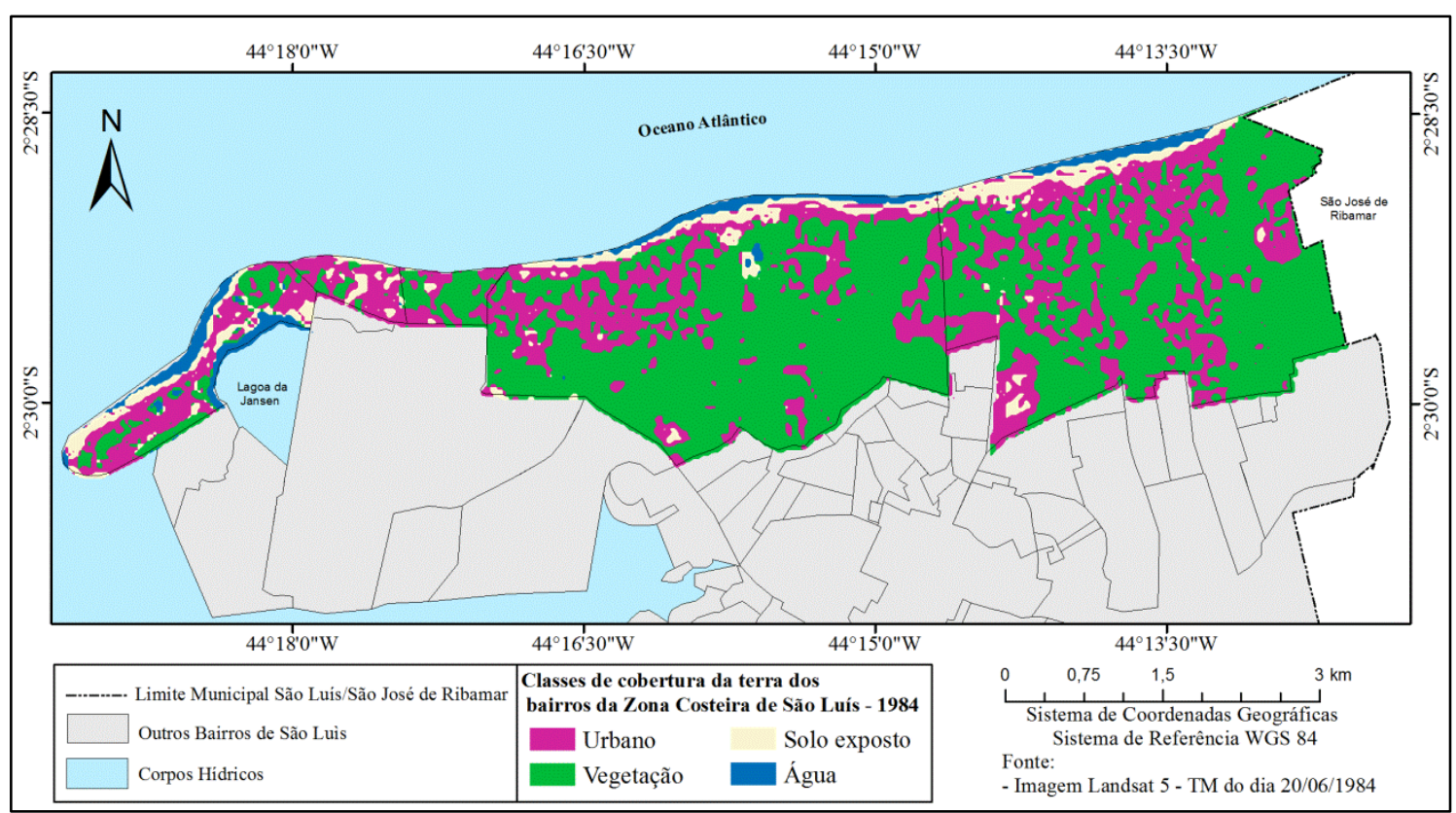

Figura 3 - Mapa de cobertura da terra da Zona Costeira Norte de São Luís, para o ano de 1984. Fonte: Organizado pelos autores (2016). 


\section{EXPANSÃO URBANA E IMPACTOS AMBIENTAIS NA ZONA COSTEIRA NORTE DO MUNICÍPIO DE SÃO LUÍS (MA)}

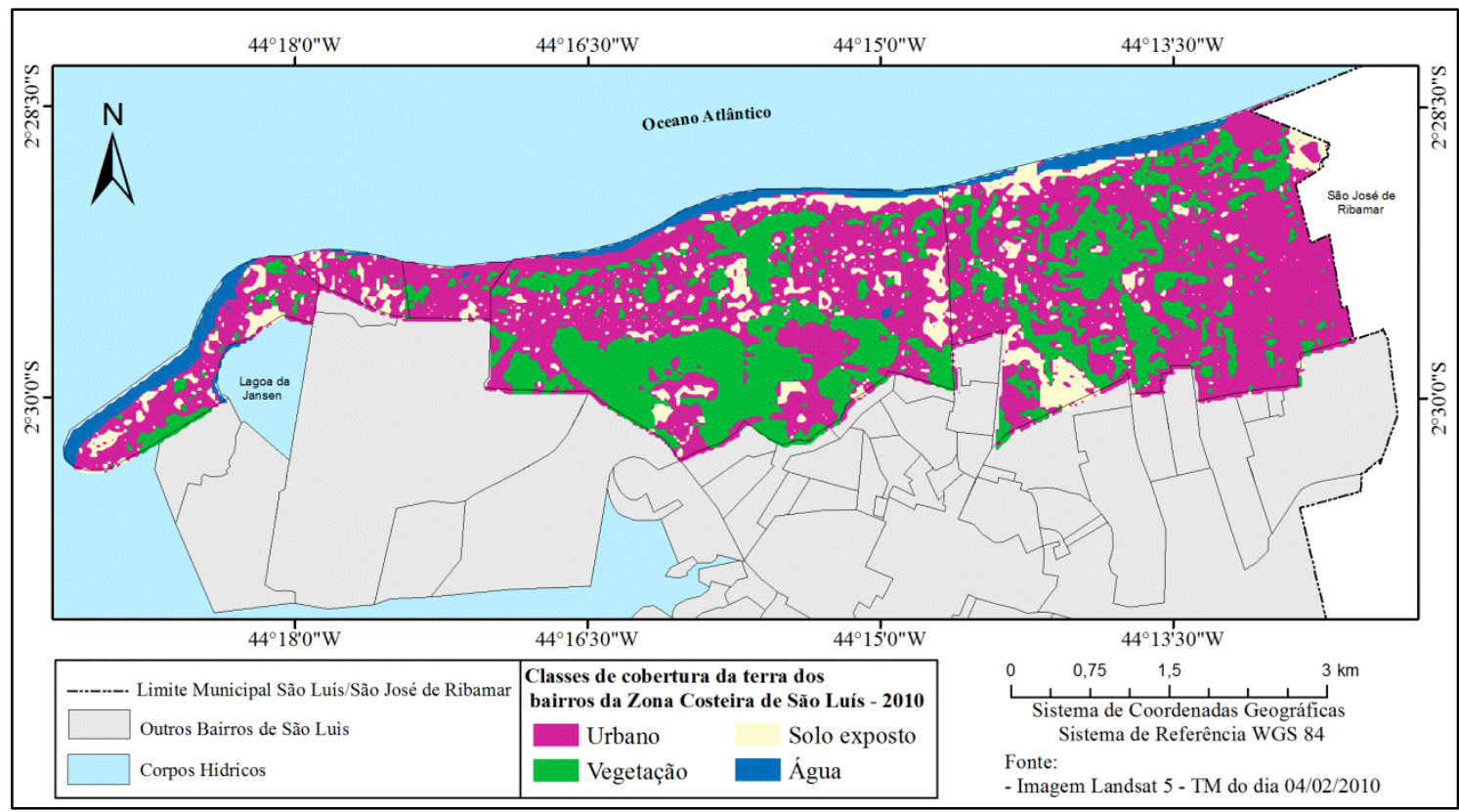

Figura 4 - Mapa de cobertura da terra da Zona Costeira Norte de São Luís, para o ano de 2010. Fonte: Organizado pelos autores (2016).

O Gráfico 2 apresenta o percentual da taxa de ocupação de cada classe mapeada na área de estudo, para as duas datas analisadas: 20 de julho de 1984 e 04 fevereiros de 2010. Percebe-se que a classe de urbano quase dobrou, uma vez que, em 1984, ocupava um total de $29,27 \%$ da área e em 2010 o total era de $56,26 \%$.

Nessa perspectiva, constata-se que a intensa alteração da cobertura da terra, resultado do processo de urbanização da cidade, provocou profundas transformações na paisagem natural, pois houve significativa redução da cobertura vegetal. Como pode ser percebido no Gráfico 2, no ano de 1984, a área com vegetação ocupava um total de $61,27 \%$ da área analisada e, em 2010, esse percentual caiu para $29,09 \%$.

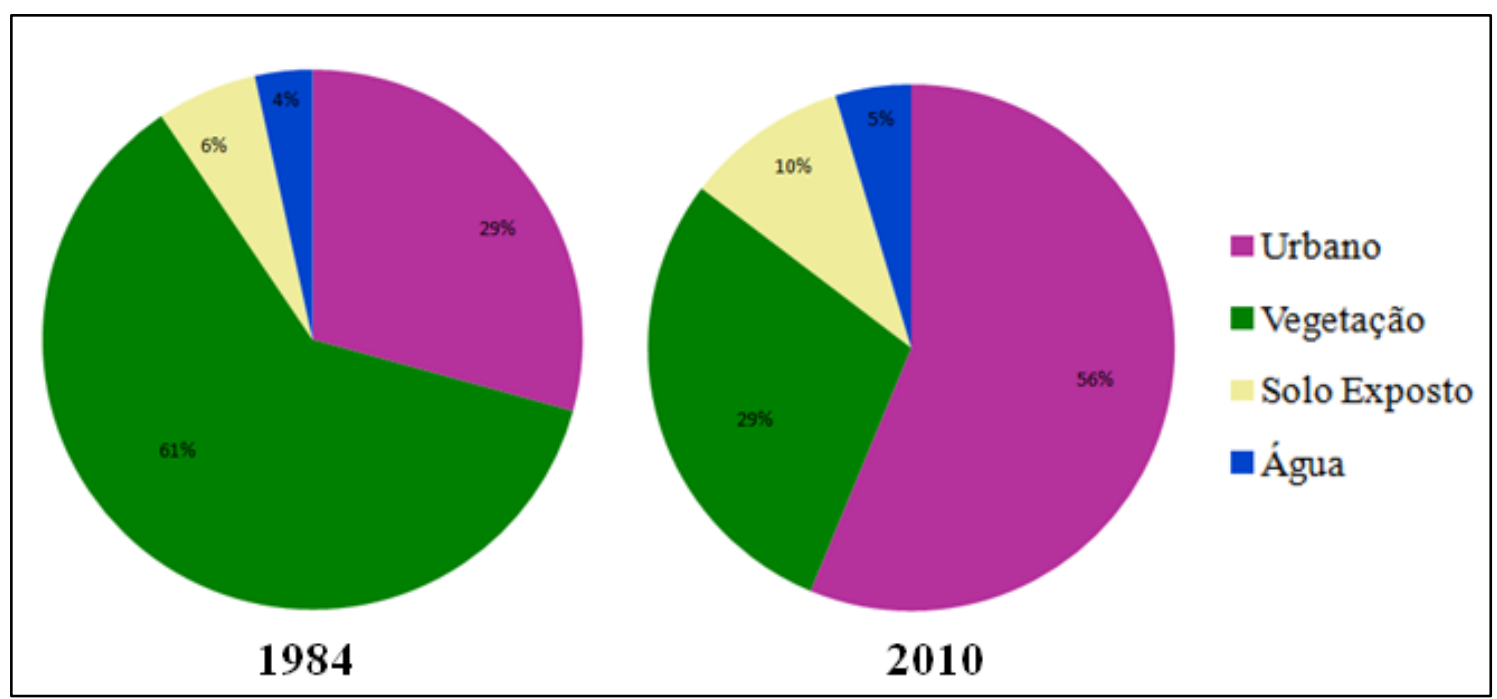

Figura 5 - Percentual de cobertura da terra da Zona Costeira de São Luís em 1984 e 2010. Fonte: Organizado pelos autores

(2016). 


\section{EXPANSÃO URBANA E IMPACTOS AMBIENTAIS NA ZONA COSTEIRA NORTE DO MUNICÍPIO DE SÃO LUÍS (MA)}

Com relação a análise dos impactos ambientais na Zona Costeira Norte de São Luís, constatou-se também, como principais ações impactantes, a supressão da cobertura vegetal e uso indevido das áreas de dunas para criação de residências de veraneio (segunda residência), para fins de lazer. Isso acontece, sobretudo, em áreas próximas à Praia do Olho d'Água. Destacamos outrossim, a construção de vias de acesso, como é o caso do prolongamento da Avenida Litorânea (construção mais recente), que contribuíram significativamente para o incremento de impactos ambientais no ambiente natural.

A Tabela 1, apresenta os dados da quantificação das classes de cobertura da terra $\left(\mathrm{km}^{2}\right.$ e \%) e o percentual de variação em 1984 e 2010. Os dados mostram que a classe de vegetação foi a que apresentou a maior taxa de variação $(-2,17 \%)$, seguida da classe urbano $(26,99 \%)$, solo exposto $(3,96 \%)$ e água $(1,22 \%)$.

\begin{tabular}{|c|c|c|c|c|c|}
\hline \multirow{2}{*}{ CLASSES } & \multicolumn{4}{|c|}{ Área $\left(\mathrm{km}^{2}\right)$} & \multirow{2}{*}{$\begin{array}{c}\text { Variação } \\
\left(\mathrm{km}^{2}\right)\end{array}$} \\
\hline & 1984 & $\%$ & 2010 & $\%$ & \\
\hline Urbano & 5,78 & 29,27 & 11,1 & 56,26 & 26,99 \\
\hline Vegetação & 12,1 & 61,27 & 5,74 & 29,09 & $-32,17$ \\
\hline Solo Exposto & 1,19 & 6,03 & 1,97 & 9,98 & 3,96 \\
\hline Água & 0,68 & 3,44 & 0,92 & 4,66 & 1,22 \\
\hline
\end{tabular}

Tabela 1 - Quantificação das classes de cobertura da terra $\left(\mathrm{km}^{2}\right.$ e \%) e percentual de variação em 1984 e 2010. Fonte: Organizado pelos autores (2016).

De acordo com os dados da classificação do uso e ocupação do solo, podese verificar que a Zona Costeira Norte de São Luís está intensamente antropizada e vários foram os processos que contribuíram para alteração da paisagem natural desse ambiente.

Conforme Lefebvre (1999), a alteração de um determinado espaço pode ser representada por vários aspectos, como por exemplo: presença de uma segunda residência, construção de uma rodovia, ou mesmo a presença de um supermercado. Tudo isso sinaliza para a chegada de uma nova dinâmica social, produzindo novas relações sociais e uma nova dinâmica no território, que como o autor enfaticamente afirmou ao longo de suas formulações, materializa-se no espaço.

\subsubsection{Avaliação do critério de confiabilidade da classificação do uso e ocupação da terra}

As Tabelas 2 e 3 apresentam as matrizes de erros das classificações das imagens de satélite, correspondente aos anos de 1984 e 2010. Os valores destacados em negrito (diagonal principal), mostram o percentual de acerto dos pixels classificados corretamente e os valores fora da diagonal principal mostram o percentual que foi classificado erroneamente em cada classe.

De acordo com Melo et al. (2008), um resultado de $100 \%$ na diagonal principal indica que os pixels da imagem foram classificados de forma correta, evidenciando que não houve confusão entre as classes mapeadas, porém esta é uma situação difícil em imagens que apresentam características espectrais semelhantes.

A matriz de erros da imagem de 1984, revela que a classe que apresentou melhor resultado foi vegetação, com uma precisão de $78,95 \%$ dos pixels e a classe que apresentou pior resultado foi solo exposto, com $4.62 \%$ de precisão (Tabela 2). A matriz de erros da imagem de 2010, mostra que a classe que apresentou o melhor resultado foi a de vegetação com 36,89\% de precisão e a menor precisão é observada na classe de solo exposto, 


\section{EXPANSÃO URBANA E IMPACTOS AMBIENTAIS NA ZONA COSTEIRA NORTE DO MUNICÍPIO \\ DE SÃO LUÍS (MA)}

com precisão de 3,85\% (Tabela 3 ). O baixo desempenho da classificação de algumas classes pode ser explicado pela região apresentar alvos com características espectrais semelhantes, como é o caso das áreas da classe urbano e solo exposto.

\section{Dados de Referência}

\begin{tabular}{c|rrcc|c}
\hline & Água & Urbano & Solo Exposto & Vegetação & $\begin{array}{c}\text { Acurácia } \\
\text { Usuário }\end{array}$ \\
\hline Água & $\mathbf{9 . 1 4 \%}$ & $0.00 \%$ & $0.00 \%$ & $0.00 \%$ & $100,00 \%$ \\
\hline Urbano & $0.00 \%$ & $\mathbf{6 . 8 3 \%}$ & $0.00 \%$ & $0.00 \%$ & $100,00 \%$ \\
\hline Solo Exposto & $0.00 \%$ & $0.18 \%$ & $\mathbf{4 . 6 2 \%}$ & $0.00 \%$ & $96,15 \%$ \\
\hline Vegetação & $0.00 \%$ & $0.18 \%$ & $0,09 \%$ & $\mathbf{7 8 . 9 5 \%}$ & $99,65 \%$ \\
\hline Acurácia Produtor & $100,00 \%$ & $94,87 \%$ & $98,04 \%$ & $100,00 \%$ & \\
\hline
\end{tabular}

Tabela 2 - Matriz de erros e acurácia da classificação do algoritmo MAXVER, para a imagem do ano de 1984. Fonte: Organizado pelos autores (2016).

\begin{tabular}{c|rrcc|c}
\hline & Água & Urbano & Solo Exposto & Vegetação & $\begin{array}{c}\text { Acurácia } \\
\text { Usuário }\end{array}$ \\
\hline Água & $\mathbf{9 . 1 4 \%}$ & $0.00 \%$ & $0.00 \%$ & $0.00 \%$ & $100,00 \%$ \\
\hline Urbano & $0.00 \%$ & $\mathbf{6 . 8 3 \%}$ & $0.00 \%$ & $0.00 \%$ & $100,00 \%$ \\
\hline Solo Exposto & $0.00 \%$ & $0.18 \%$ & $\mathbf{4 . 6 2 \%}$ & $0.00 \%$ & $96,15 \%$ \\
\hline Vegetação & $0.00 \%$ & $0.18 \%$ & $0,09 \%$ & $\mathbf{7 8 . 9 5 \%}$ & $99,65 \%$ \\
\hline Acurácia Produtor & $100,00 \%$ & $94,87 \%$ & $98,04 \%$ & $100,00 \%$ & \\
\hline
\end{tabular}

Tabela 3 - Matriz de erros e acurácia da classificação do algoritmo MAXVER, para a imagem do ano de 2010. Fonte: Organizado pelos autores (2016).

A Tabela 4, mostra o desempenho geral da classificação, das imagens de 1984 e 2010, pelo algoritmo MAXVER. Embora a matriz de erro (Tabela 2 e Tabela 3), mostre que algumas classes apresentam baixo desempenho da classificação, verifica-se que o classificador apresentou um bom desempenho geral $(99,54$
$\%)$, isto significa, que o mapeamento teve a probabilidade de acerto de 99,54\%, implicando em uma confusão média de apenas $0,46 \%$, para o ano de 1984, e desempenho geral de 99,31\% e confusão média de $0,69 \%$, para o ano de 2010.

\begin{tabular}{|c|c|c|c|c|c|}
\hline \multirow{3}{*}{ 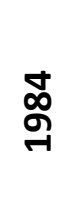 } & Desempenho geral & $99,54 \%$ & \multirow{3}{*}{ 웅 } & Desempenho geral & $99,31 \%$ \\
\hline & Confusão média & $0,46 \%$ & & Confusão média & $0,69 \%$ \\
\hline & Abstenção média & $0,00 \%$ & & Abstenção média & $0,00 \%$ \\
\hline
\end{tabular}

Tabela 4 - Desempenho da matriz de erros do algoritmo MAXVER referente aos anos de 1984 e 2010. Fonte: Organizado pelos autores (2016). 


\section{EXPANSÃO URBANA E IMPACTOS AMBIENTAIS NA ZONA COSTEIRA NORTE DO MUNICÍPIO DE SÃO LUÍS (MA)}

4.2. Principais impactos ambientais da Zona Costeira Norte de São Luís-MA

A Resolução CONAMA no 001, de 23 de janeiro de 1986, em seu Artigo 1으, considera que impacto ambiental é "qualquer alteração das propriedades físicas, químicas e biológicas do meio ambiente, causada por qualquer forma de matéria ou energia resultante das atividades humanas". Silva; Farias Filho (2015), salientam que "uma das áreas que tem sofrido grandes impactos decorrentes do uso inapropriado é a Zona Costeira, sua beleza cênica e as grandes riquezas naturais funcionam como forte atrativo para sua ocupação." Assim como em diversos municípios da Zona Costeira do Brasil, no município de São Luís - MA é observada também a intensificação dos impactos ambientais, decorrentes das inúmeras alterações no ambiente natural causada pelo uso e ocupação do solo.
No trabalho de campo realizado durante esta pesquisa foi possível observar os seguintes impactos no ambiente costeiro de São Luís - MA: especulação imobiliária (crescimento da rede hoteleira e construção de novos condomínios), residências de segunda moradia sobre áreas de preservação, privatização dos espaços das praias por barracas, despejo de efluentes in natura e disposição inadequada de resíduos sólidos.

A Figura 4, apresenta uma visão panorâmica da ocupação urbana intensa da Zona Costeira Norte de São Luís, onde destacase também o processo de verticalização, avançando inclusive sobre áreas de preservação permanente (APP). A Figura 5, mostra residências construídas na antepraia (local de preservação ambiental), na Praia do Meio.

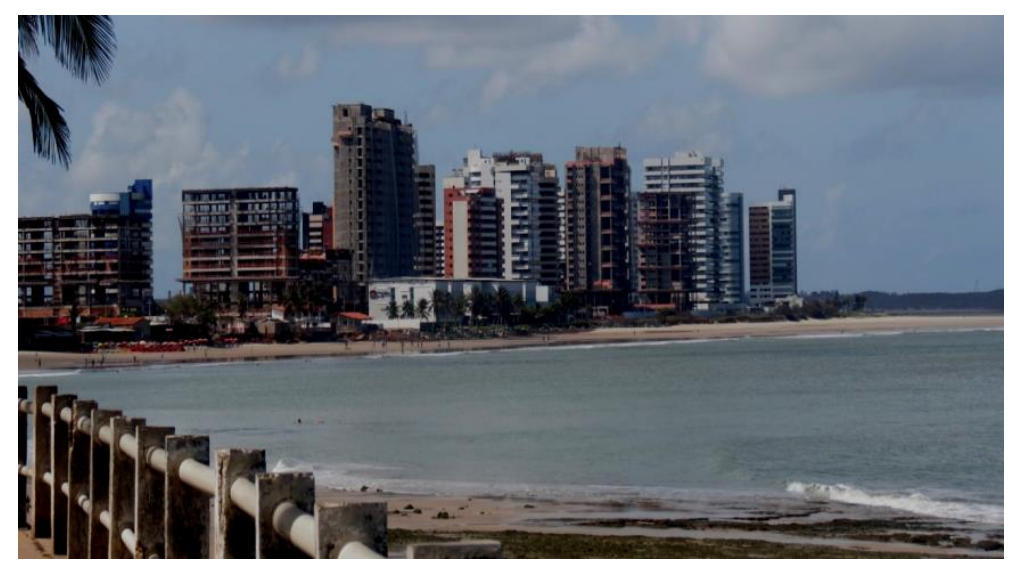

Figura 4 - Expansão urbana na Zona Costeira de São Luís - MA, processo de verticalização. Fonte: Dados da pesquisa/Janeiro de 2014

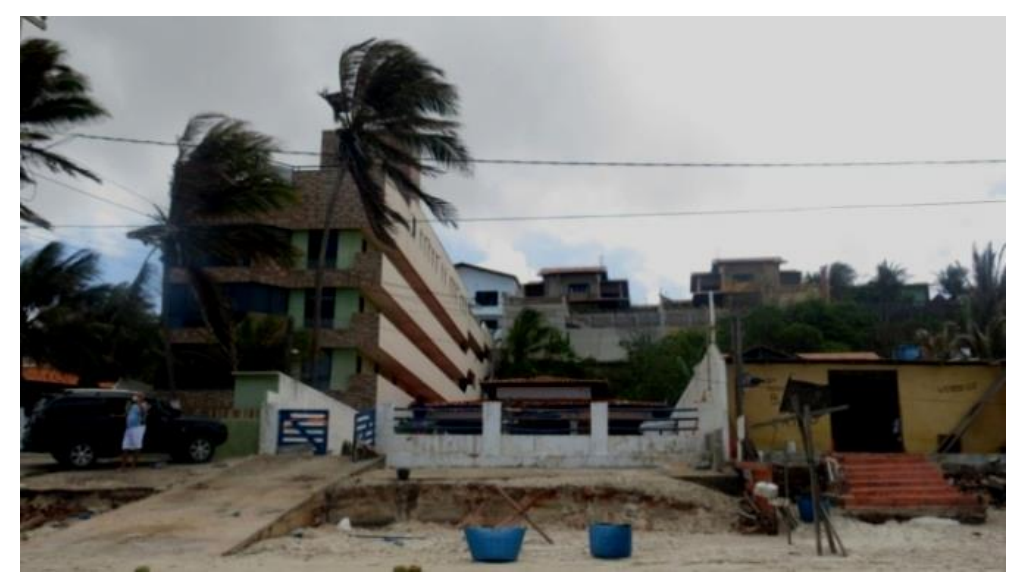

Figura 5 - Residências construídas em antepraia - Praia do Meio. Fonte: Dados da pesquisa/Janeiro de 2014 


\section{EXPANSÃO URBANA E IMPACTOS AMBIENTAIS NA ZONA COSTEIRA NORTE DO MUNICÍPIO DE SÃO LUÍS (MA)}

Na praia do Calhau, também é possível observar, a ocupação de espaços indevidos. Em trechos próximos ao prolongamento da avenida
Litorânea, aconteceu o processo de ocupação irregular das áreas de cordões de dunas (Figura $6)$.

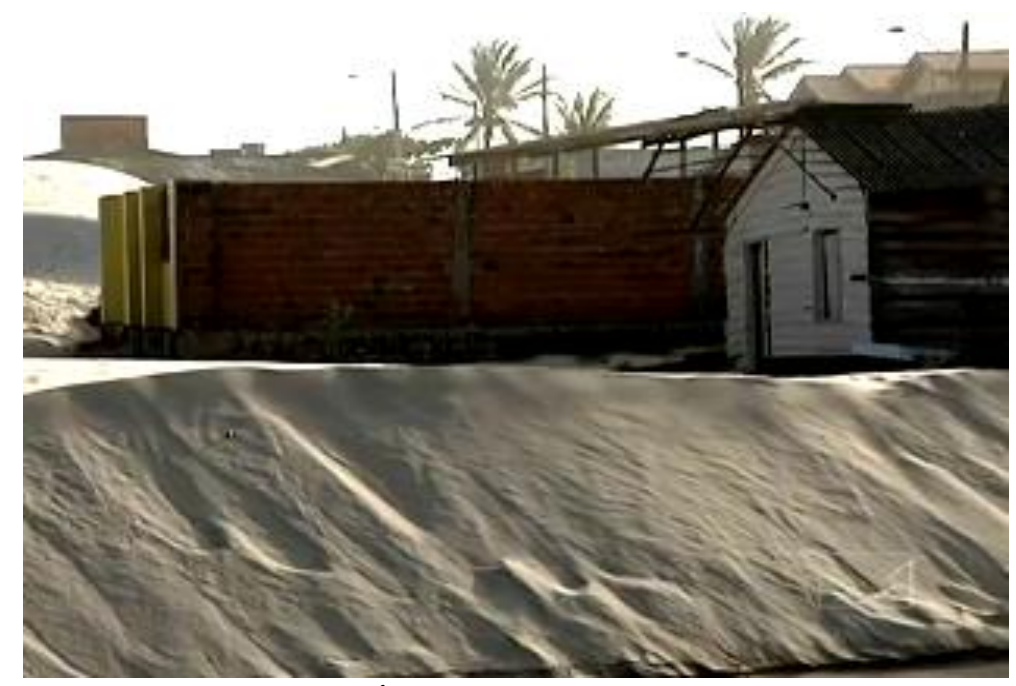

Figura 6 - Ocupação em áreas de dunas (Área de Proteção Ambiental) promovendo a desconfiguração da paisagem dunar - Praia do Calhau. Fonte: Dados da pesquisa/Janeiro de 2014.

Também caracteriza-se como uso indevido da Zona Costeira, o livre trânsito de carros na orla marítima de São Luís, pois este tipo de uso contribui para a compactação e/ou revolvimento da areia, promovendo as alterações físicas em diversas zonas, afetando negativamente os ecossistemas localizados nesse ambiente. (Figura 7)

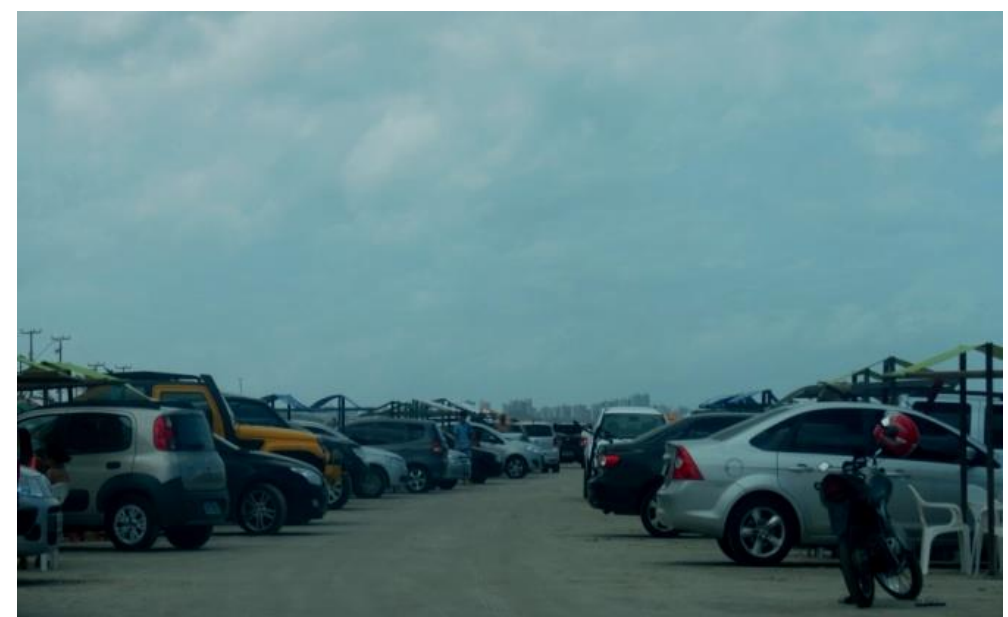

Figura 7 - Tráfego de veículos sobre a faixa de estirâncio - Praia do Olho d'Água. Fonte: Dados da pesquisa/Janeiro de 2014.

Ao mencionar os impactos ambientais da Zona Costeira Norte de São Luís, é de fundamental importância, considerar neste estudo, as questões relacionadas ao saneamento básico, uma vez que, em decorrência da ineficiência dos serviços prestados pela Companhia de Saneamento
Ambiental do município, constata-se, que em diversos pontos, o esgoto é lançado sem tratamento na orla de São Luís, contribuindo para a contaminação da água, tornando alguns pontos impróprios para banho, como pode ser observado na Figura 8. 


\section{EXPANSÃO URBANA E IMPACTOS AMBIENTAIS NA ZONA COSTEIRA NORTE DO MUNICÍPIO DE SÃO LUÍS (MA)}
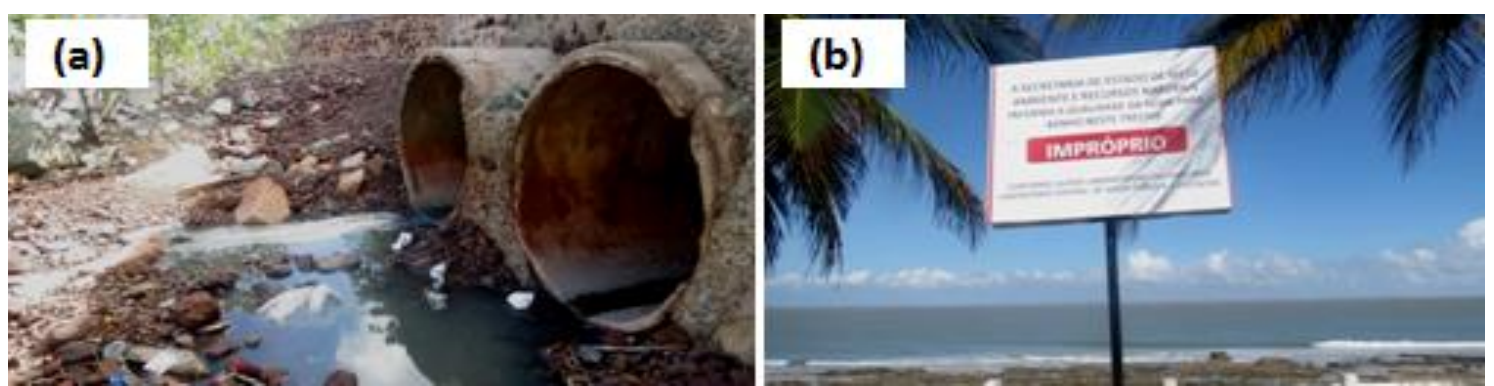

Figura 8 - (a) Despejo de esgoto in natura nas areias nas praias (b) Área imprópria para banho Praia da Ponta d’Areia. Fonte: Dados da pesquisa/Janeiro de 2014.

4.3. Instrumentos de gestão urbana aplicados ao planejamento ambiental da Zona Costeira de São Luís

Considerando que a criação da lei que institucionalizou o Gerenciamento Costeiro no Brasil ocorreu há mais de 20 anos, constata-se que o processo de gerenciamento ainda caminha a passos lentos. Segundo Portz (2011, p. 462), “apenas 8 dos 17 Estados costeiros, apresentam órgãos específicos para tratar deste assunto e 9 Estados possuem um plano de gerenciamento costeiro". Dentre os Estados que não apresentam o Plano de Gerenciamento Costeiro está o Maranhão, o que tende a dificultar ainda mais a gestão desse espaço, considerando as diretrizes especificas que um Plano de Gerenciamento Costeiro, a nível estadual ou municipal, poderia ter.

Outra implicação com relação aos instrumentos de gestão costeira é a não participação do município de São Luís no Projeto Orla. Considera-se que o projeto é um importante instrumento de gestão costeira e a real aplicabilidade desse projeto poderia contribuir para a proteção da costa do município. Dorneles (2008), aponta que "os objetivos específicos do referido projeto são fortalecer a articulação dos diferentes atores do setor público para a gestão integrada da orla, aperfeiçoando o arcabouço normativo para o ordenamento de usos e ocupação desse espaço".

Os instrumentos de gestão territorial, aplicados ao planejamento ambiental, são fundamentais para disciplinar o uso e ocupação da Zona Costeira e, a partir de então, criar propostas em que o ordenamento territorial e o disciplinamento dos usos do solo, como eixo articulador na mitigação de impactos, possam assegurar a preservação da costa. No entanto, no município de São Luís, a inexistência de instrumentos específicos de gestão desse espaço, a pouca aplicabilidade dos instrumentos de gestão existentes e a falta de fiscalização pelos órgãos gestores competentes, são os aspectos que impedem que o uso e ocupação dessas áreas sejam melhor planejados.

Considerando a inexistência de leis e diretrizes especificas para o planejamento do uso e ocupação da Zona Costeira de São Luís, a exemplo, o Projeto Orla se mostra como instrumento de gestão desse espaço a lei de Zoneamento, Parcelamento, Uso e Ocupação do Solo Urbano instituída pela lei 3.253, de 29 de dezembro de 199, Plano Diretor, criado pela lei no 4.669 de 11 de outubro de 2006 e a Lei Orgânica Municipal.

\subsubsection{Lei de Zoneamento, Parcelamento, Uso e Ocupação do Solo Urbano}

A Lei № 3.253, de dezembro de 1992 que dispõe do Zoneamento, Parcelamento, Uso e Ocupação do Solo Urbano, define no Artigo 1ㅇ as "normas de parcelamento e uso do solo do Município, bem como estabelece as intensidades de ocupação, utilização e as atividades adequadas, toleradas e proibidas" tendo em vista os seguintes objetivos:

\footnotetext{
I. Orientar e estimular o desenvolvimento urbano;
} 


\section{EXPANSÃO URBANA E IMPACTOS AMBIENTAIS NA ZONA COSTEIRA NORTE DO MUNICÍPIO DE SÃO LUÍS (MA)}

II. Minimizar a existência de conflitos entre as áreas residenciais e outras atividades sociais e econômicas;

III. Permitir o desenvolvimento racional e integrado do aglomerado urbano;

IV. Assegurar a concentração urbana equilibrada, mediante o controle do uso e do aproveitamento do solo;

V. Assegurar a reserva de espaços necessários à expansão disciplinada da cidade (LEI MUNICIPAL № 3.253, Artigo 1).

Conforme a lei de Zoneamento, Parcelamento, Uso e Ocupação do Solo Urbano, ficou estabelecido que a Zona Costeira de São Luís está inserida em duas importantes Zonas de Proteção Ambiental: a ZPA 1 e a ZPA 2. A Zona de Proteção Ambiental, conforme o Artigo 242, é a área que pelos seus elementos naturais, merece tratamento especial com a finalidade de preservar, recuperar ou revitalizar o meio ambiente. Desta maneira, os Artigos 74 e 81 apresentam a situação geográfica dessas duas zonas ambientais.

Art. 74 - A Zona de Proteção Ambiental 1 situase na área de interesse paisagístico ao longo das praias e compreende os logradouros e edificações existentes no seu interior.

Art. 81 - As Zonas de Proteção Ambiental 2 situam-se em áreas de terra firme e de proteção às bacias hidrográficas, lagos, lagoas, mangues, igarapés, rios e outras áreas inundáveis por marés, sendo considerada de preservação ambiental todo o interior e uma faixa externa de $50,00 \mathrm{~m}$ (cinqüenta metros), a partir de suas margens (LEI MUNICIPAL, № 3.253, Artigo 74 e 81).

No Artigo 6으, incisos XXVII, XXVIII e $X X X$, são traçados os limites das zonas de proteção ambiental de São Luís, ratificando, uma vez mais que a área de estudo desta pesquisa- a Zona Costeira Norte de São Luís -, está inserida na área de proteção ambiental, conforme se observa na Figura 9.

XXVII - ZONA DE PROTEÇÃO AMBIENTAL 1 ZPA1 (SÃO MARCOS)

Inicia-se este limite de interseção do prolongamento da Av. Atlântica com a Av. São Marcos, seguindo pela primeira até encontrar o limite da ZR8 Calhau), prosseguindo ao longo deste limite rumo à direita, passando pela Rua Ibiapaba, Rua 40, Av. A e Rua 01, até o encontro da última com o limite da ZTX - São Marcos; a partir deste ponto prossegue com rumo à direita por este limite até atingir o ponto inicial deste perímetro.

XXVIII - ZONA DE PROTEÇÃO AMBIENTAL 1 ZPA1 (CALHAU)

Inicia-se este limite no ponto de interseção da linha de preamar do Rio Calhau com a Av. Atlântica, seguindo pela última, inclusive seu prolongamento, até atingir a linha de preamar do Rio Claro, prosseguindo por esta até encontrar o ponto de interseção da Rua Lina Figueiredo com a Rua Jardim de Allah; deste ponto segue à direita, acompanhando o limite da ZR8 - Jardim de Allah, passando pela Rua Lina Figueiredo e a Av. Vale do Rio Pimenta (margem do Rio Pimenta), até encontrar a Av. dos Holandeses; daí prossegue pela outra margem do Rio Pimenta acompanhando o limite da ZR8 Quintas do Calhau, passando pela linha de preamar do Rio Calhau até encontrar a Av. dos Holandeses; daí prolonga-se pela outra margem do Rio Calhau, acompanhando o limite da ZR8 Calhau (linha de preamar do Rio Calhau), até atingir o ponto inicial deste limite.

XXX - ZONA DE PROTEÇÃO AMBIENTAL 2 - ZPA2 Os limites desta Zona estão compreendidos pela área do entorno das bacias hidrográficas, correntes, rios, riachos, pontes, lagos e lagoas periodicamente inundáveis pela própria bacia ou marés, que estão contidas em todo território municipal, concluindo este perímetro (LEI MUNICIPAL № 3.253, Artigo 6ㅇ). 


\section{EXPANSÃO URBANA E IMPACTOS AMBIENTAIS NA ZONA COSTEIRA NORTE DO MUNICÍPIO DE SÃO LUÍS (MA)}

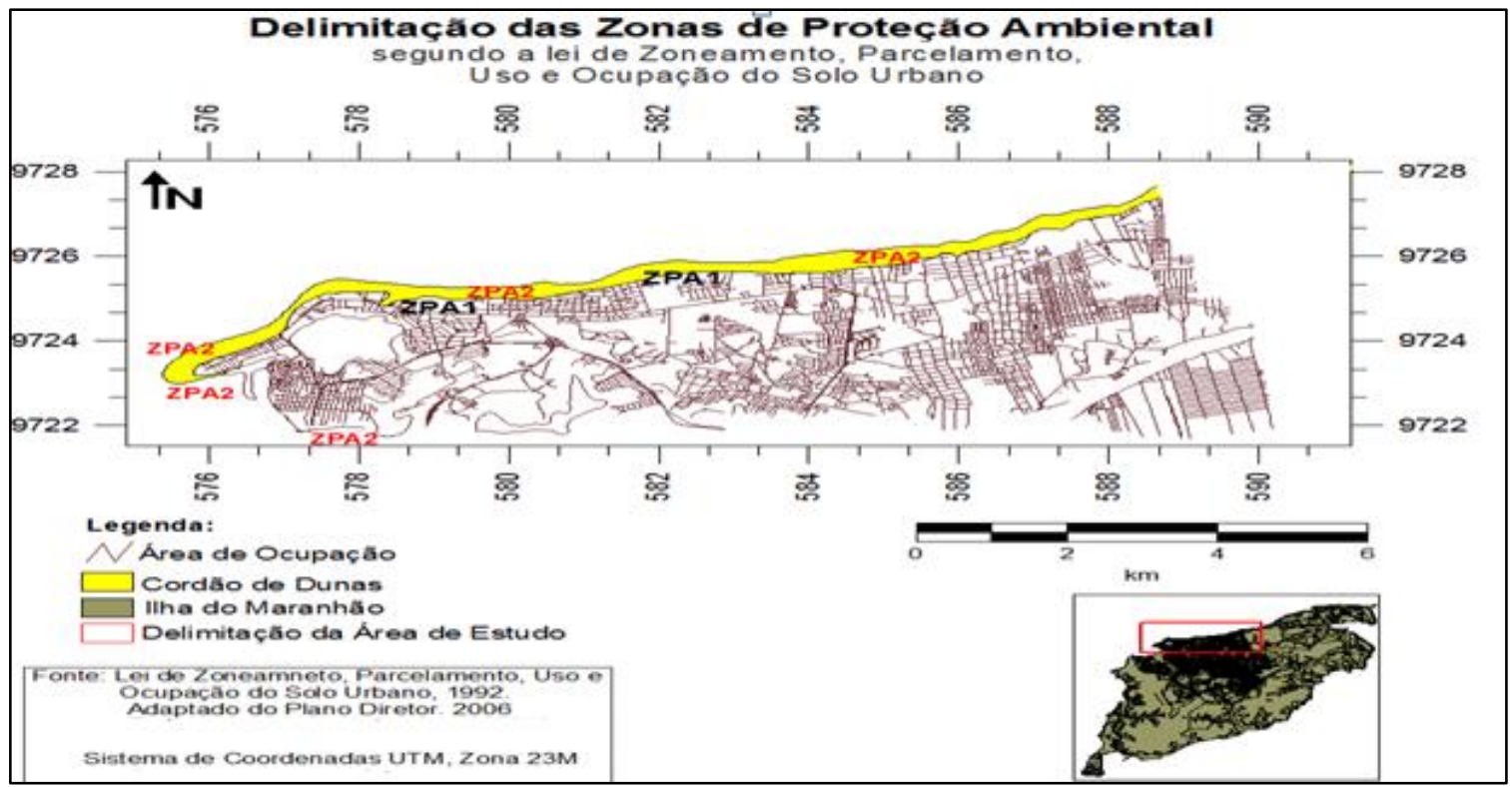

Figura 9 - Delimitação das Zonas de Proteção Ambiental, segundo a lei de Zoneamento, Parcelamento, Uso e Ocupação do Solo Urbano. Fonte: Elaborado pela autora (2013), com base no Plano Diretor Municipal, 2006.

O Artigo 189 da lei № 3.253 esclarece que não é permitido o uso e ocupação das áreas que apresentam formação de dunas, ou seja, não é permitido o uso e ocupação da Zona de Proteção Ambiental 1 - ZPA 1, salvo em casos especiais e após análise criteriosa realizada pelos órgãos competentes. Entretanto, nas visitas de campo feitas durante esta pesquisa, constatou-se que nessa área estão alguns dos principais impactos ambientais da área de abrangência da Zona Costeira de São Luís.

Nota-se que, embora a lei que define o Zoneamento, Parcelamento, Uso e Ocupação do Solo Urbano apresente uma delimitação bastante criteriosa no que diz respeito ao uso e ocupação do solo urbano do município de São Luís, contata-se que os critérios estabelecidos não estão sendo utilizados na elaboração do planejamento, do uso e ocupação da Zona Costeira Norte de São Luís.

\subsubsection{Plano Diretor}

De acordo com a lei no 4669, de 11 de outubro de 2006, que dispõe sobre o Plano Diretor do município de São Luís, define-se tal disposto como o principal instrumento normativo e orientador da política de desenvolvimento urbano e rural com sustentabilidade socioambiental de São Luís. No Plano Diretor, é estabelecido o Macrozoneamento Ambiental, que tem por objetivo identificar partes do território de São Luís em que a preservação do ambiente é questão prioritária, sendo obrigatória à manutenção das características e da qualidade do ambiente natural. O Macrozoneamento Ambiental divide-se as áreas a serem protegidas em dois grupos, com características específicas: Áreas de Proteção Integral e Áreas de Uso Sustentável.

Conforme o Macrozoneamento Ambiental, as áreas de praias estão inseridas na no grupo de Uso Sustentável. Estas áreas, assim como esclarece o Art. 29, são espaços destinados a garantir a perenidade dos recursos ambientais renováveis e dos processos ecológicos, mantendo a biodiversidade de forma socialmente justa e economicamente viável. No parágrafo primeiro deste mesmo artigo (Artigo 29), ficou estabelecido que o objetivo das Áreas de Uso Sustentável é compatibilizar a conservação da natureza com o uso sustentável dos recursos naturais. Já no parágrafo segundo, por sua vez, são 


\section{EXPANSÃO URBANA E IMPACTOS AMBIENTAIS NA ZONA COSTEIRA NORTE DO MUNICÍPIO DE SÃO LUÍS (MA)}

apresentados os espaços que compõem a Área de Uso Sustentável:

\author{
I - Área de Proteção Ambiental do Maracanã; \\ II - Área de Proteção Ambiental do Itapiracó; \\ III - o Parque Ecológico da Lagoa da Jansen; \\ IV - o Sítio Santa Eulália; \\ V - os Parques Urbanos do Bom Menino, do \\ Diamante e do Rio das \\ Bicas; \\ VI - Áreas de Praias; \\ VII - Áreas de Recarga de Aqüífero (LEI \\ MUNICIPAL, no 4.669, Artigo 29).
}

O macrozoneamento tem como objetivo subsidiar as políticas de intervenção do solo urbano, por parte do poder público e setor privado e, assim, possibilitar que a função social da cidade possa ser assegurada. Conforme o Art. 1으, inciso I, do Plano Diretor Municipal, a função social da cidade é assim conceituada:

\begin{abstract}
FUNÇÃO SOCIAL DA CIDADE é a função que deve cumprir a cidade para assegurar a plena realização dos direitos de todos os cidadãos à moradia digna, aos serviços públicos de saneamento ambiental, infraestrutura, transporte, educação, saúde, cultura, esporte, lazer, trabalho, segurança, acessibilidade e mobilidade, informação, participação e decisão no processo de planejamento territorial municipal( LEI MUNICIPAL, n 4.669, Artigo 1ㅇ).
\end{abstract}

O Artigo 83 do Plano Diretor de São Luís trata dos princípios e diretrizes da Política do Meio Ambiente, Paisagem e Saneamento Ambiental e apresenta uma proposta de gestão integrada. Este artigo determina que: "a gestão integrada do meio ambiente deve manter a transversalidade das ações entre as secretarias e órgãos da administração direta e indireta do município, bem como dos outros órgãos competentes".

\subsubsection{Lei Orgânica de São Luís}

A Lei Orgânica de São Luís, no Capitulo III, Artigo 13, inciso VI, esclarece que "compete ao Município em comum com a União e com o Estado proteger o meio ambiente e combater a poluição em qualquer de suas formas". Na seção IV, Artigo 181, parágrafo $2 \stackrel{0}{ }$, percebe-se que o Município, na defesa da preservação da natureza e do ecossistema não permitirá:

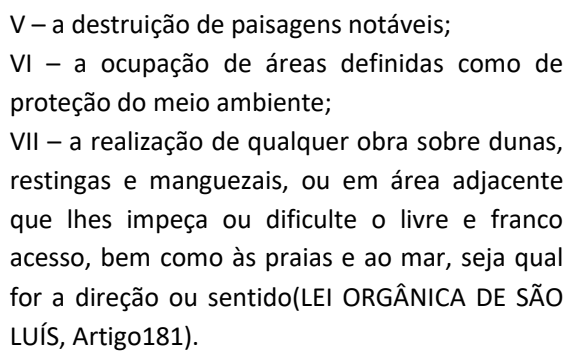

No Artigo 189 da Lei Orgânica do Município de São Luís, fica estabelecido a proibição de construções de edifícios com taxa de ocupação superior a $50 \%$ dos lotes ao longo das praias de São Luís e em uma distância de até 500 metros da linha de maré alta. Conforme pode ser observado na visita de campo na área de estudo desta pesquisa, várias construções que estão inseridas na Zona Costeira Norte de São Luís estão em desacordo com esta norma. Algumas construções, além de terem sido edificadas na área do cordão de dunas, ainda estão dentro da área que deveria ser destinada a dinâmica das marés, como é o caso principalmente das casas de veraneio.

Ainda em conformidade com a Lei Orgânica de São Luís, cabe ao município assegurar a preservação dos córregos, rios e igarapés nas áreas de seu território e a preservação de dunas na orla marítima. De acordo com a lei mencionada, fica proibido o lançamento nas praias, lagoas, rios e córregos de São Luís, de detritos e dejetos de qualquer natureza, sujeitando-se seus responsáveis a sanções por danos ecológicos, nos termos da lei.

Existem outros instrumentos importantes para a gestão do uso do solo urbano, a exemplo do Estatuto da Cidade. Conforme Paula (2013), as diretrizes previstas no Estatuto da Cidade atribui ao município a responsabilidade sobre o controle do uso e ocupação do solo das zonas urbanas, na perspectiva do desenvolvimento econômicosocial integrado do território sob sua área de influência. 


\section{EXPANSÃO URBANA E IMPACTOS AMBIENTAIS NA ZONA COSTEIRA NORTE DO MUNICÍPIO DE SÃO LUÍS (MA)}

\section{CONSIDERAÇÕES FINAIS}

Esta pesquisa revelou que, na Zona Costeira Norte de São Luís (MA), o processo de urbanização está expresso principalmente no adensamento da malha urbana da cidade, em consequência do crescimento populacional.

Nas visitas de campo à área de estudo, foram verificados intensos impactos aos sistemas ambientais costeiros (praias, dunas e manguezais). Tais impactos ocorreram devido a intensificação das ocupações urbanas (condomínios verticais e horizontais, casas de veraneio e hotéis) sobre estes ambientes litorâneos.

Salienta-se que diversos tipos de ocupações ocorreram de forma irregular e sem considerar as diretrizes estabelecidas nos instrumentos de gestão urbana (leis e planos). Este quadro de problemas desencadeou uma série de alterações na paisagem natural.

A degradação da paisagem e a retração de habitats verificadas na área levam a perda da biodiversidade, simplificando as funções ecossistêmicas e diminuindo os serviços dos ecossistemas que são importantes para o bem estar humano.

As informações -espaciais do uso e cobertura da terra, obtidas a partir da classificação de imagens de satélite, em ambiente SIG, revelam que nos bairros da Zona Costeira Norte de São Luís houve intenso processo de urbanização e, consequentemente, redução significativa das áreas com cobertura de vegetação.

No que se refere aos instrumentos legais de planejamento do uso e ocupação do solo (leis e planos), é importante considerar que eles são instrumentos de planejamento territorial que visam identificar, avaliar e minimizar e/ou impedir os impactos. No entanto, é necessário que, de fato, as leis e planos de gestão estejam inseridos no processo de planejamento do território. Não devem ser planos que são apenas elaborados e, posteriormente, engavetados. Salienta-se ainda, no caso de São Luís, a necessidade do estabelecimento de leis especificas direcionadas para a gestão do espaço da Zona Costeira é urgente.

As técnicas de sensoriamento remoto, combinadas com o uso do Sistema de Informações Geográficas (SIG) são consideradas ferramentas de suma importância para a construção de modelos de representação do espaço terrestre. Nesta pesquisa, o uso desses instrumentos permitiu a criação de um banco de dados específicos da área de estudo e contribuiu para a geração de informações para o desenvolvimento desta pesquisa.

\section{REFERÊNCIAS}

BATISTA, E. D. M.; SOUZA FILHO, P. W. M.; SILVEIRA, O. F. M. D. Avaliação de áreas deposicionais e erosivas em cabos lamosos da Zona Costeira Amazônica através da análise multitemporal de imagens de sensores remotos. Revista Brasileira de Geofísica, v. 27, suppl.1, p. 83-96, 2009.

Brasil. Resolução CONAMA № 001, de 23 de janeiro de 1986. Disponível em: <http://www.mma.gov.br> Acesso em: 03/02/2015

COSTA, M. T. S. P.; OLIVEIRA, N. M. G. S. Avaliação geoambiental da Zona Costeira do bairro de Candeias, Pernambuco. Revista Mercator, v. 8, n. 17, p. 163 a 179, 2009.

DIAS, R. L.; OLIVEIRA, R. C. Zoneamento geoambiental do litoral sul do Estado de São Paulo. Geografia, Rio Claro, v. 38, n. 2, p. 371383, 2013.

DINIZ, J. S. As condições e contradições no espaço urbano de São Luís (MA): traços periféricos. Ciências Humanas em Revista, v. 5, n.1, p. 169-171, 2007.

DORNELLES, L. M. A. Educação Ambiental e Gerenciamento Costeiro. REMEA - Revista Eletrônica do Mestrado de Educação Ambiental, v. 21, n. 2, p. 75-92, 2012.

GRIGIO, A. M.; AMARO, V. E.; DIODATO, M. A. Dinâmica espaço-temporal do uso e ocupação do solo, no período de 1988 a 2004, do baixo curso do rio Piranhas-Assu (RN): sugestões de acompanhamento integrado das 


\section{EXPANSÃO URBANA E IMPACTOS AMBIENTAIS NA ZONA COSTEIRA NORTE DO MUNICÍPIO DE SÃO LUÍS (MA)}

atividades socioeconômicas impactantes em área costeira. Geografia, v. 34, n. 1, p. 141-161, 2009.

IBGE. Sinopse do Censo Demográfico. Disponível em: <http://www.censo2010.ibge.gov.br/sinopse/> Acesso em: 10/01/2015

IBGE. Atlas geográfico das zonas costeiras e oceânicas do Brasil. 2011. ISBN = 9788524042195

KAWAKUBO, F. S.; LUCHIARI, A.; MORATO, R. G. Análise comparativa das imagens TM/LANDSAT 5 e HRV-SPOT no mapeamento da cobertura vegetal no litoral sul do estado de São Paulo. Geografia, v. 28, n. 2, p. 279-289, 2003.

LEFEBVRE, H. A revolução urbana. Belo Horizonte: Editora da UFMG, 199

LIMA, E. Q.; AMARAL, R. F. VULNERABILIDADE DA ZONA COSTEIRA DE PITITINGA/RN,

BRASIL. Revista Mercator, v. 12, n. 28, p. 141153, 2013.

MARANHÃO. Secretaria de Estado do Meio Ambiente e Recursos hídricos. Coordenadoria de Programas Especiais. Programa Estadual de Gerenciamento Costeiro. Macrozoneamento do Golfão Maranhense; Diagnóstico Ambiental da Microrregião da Aglomeração Urbana de São Luís e dos Municípios de Alcântara, Bacabeira e Rosário. Estudo Sócio-Ambiental. São Luís:Sema/MMA/PNMA, 1998, p. 29.

6.1.1.

MARQUES, G. M. Uma Estratégia de Desenvolvimento para São Luís - MA L Brasil. Inglaterra., 2006. Dissertação (Planejamento Urbano em Países em Desenvolvimento). Oxford Brookes University, 2006, p. 63.

MEIRELES, A. J. A. Impactos ambientais decorrentes da ocupação de áreas reguladoras do aporte de areia: a planície Costeira da Caponga, município de Cascavel, litoral leste cearense. Confins. Revue franco-brésilienne de géographie/Revista franco-brasilera de geografia, n. 2, v.1, p. 2008.
MELO, L. F. S; ALVES,C. M. D; VIEIRA, V. C. B. Geoprocessamento aplicado a identificação dos pontos de degradação ambiental na margem direita do rio Parnaíba em Teresina Piauí. Anais II Simpósio Brasileiro de Ciências Geodésicas e Tecnologias da Geoinformação, 2008.

PARANHOS FILHO, A. C. Análise geo-ambiental multitemporal: o estudo de caso da região de Coxim e da bacia do Taquarizinho (MS - Brasil). Tese (Doutorado em Geologia) - Universidade Federal do Paraná, Curitiba, 2000.

PAULA, A. S. D.; BARROS, O. N. F.; CAINZOS, R. L. P.; RALICHI, R. Dinâmica da ocupação e uso do solo em Londrina (PR): um olhar sobre a interface urbano-rural. Confins. Revue francobrésilienne de géographie/Revista francobrasilera de geografia, n. 17, v.1, 2013.

PORTZ. L.; MANZOLLI R. P.; CORRÊA I. C. S. Ferramentas de Gestão Ambiental Aplicadas na Zona Costeira do Rio Grande do Sul, Brasil. Revista da Gestão Costeira Integrada, v. 11, n. 4, p. 459-470, 2011.

SANTOS, M. Metamorfoses do espaço habitado. 5. ed., São Paulo: Hucitec, 1997.

São Luís. Lei 3.253, de 29 de dezembro de 1992. Dispõe Sobre o Zoneamento, Parcelamento, Uso e Ocupação do Solo Urbano.

São Luís. Lei no 4.669 de 11 de outubro de 2006. Dispõe sobre o Plano Diretor do Município de São Luís.

São Luís. Lei Orgânica Municipal de São Luís. Dispõe sobre a criação, organização e supressão de distritos em São Luís.

SILVA, I. R.; SILVA, S. B. M. Caracterização geoambiental e de ocupação das praias da costa do dendê, litoral sul do estado da Bahia. Geosul, Florianópolis, v. 22, n. 44, p 27-46, 2007.

SILVA, I. R.; BITTENCOURT, A. C. D. S. P.; DOMINGUEZ, J. M. L.; MELLO, S. B. Uma contribuição à gestão ambiental da Costa do Descobrimento (litoral sul do Estado da Bahia): Avaliação da qualidade recreacional das praias. Geografia, v. 28, n. 3, p. 397-414, 2008. 
EXPANSÃO URBANA E IMPACTOS AMBIENTAIS NA ZONA COSTEIRA NORTE DO MUNICÍPIO

DE SÃO LUÍS (MA)

SILVA, J. S; FARIAS FILHO, M. S. Instrumentos legais de prevenção de impactos ambientais na Zona Costeira: estratégias integradas de gestão territorial. REMEA - Revista Eletrônica do Mestrado de Educação Ambiental, v. 32, n. 2, p. 7-25, 2015. 